Joanna Pietrzak-Thébault

Warszawa

\title{
Warząchiew, mydło, igła. Książka na służbie (Wenecja, XVI w.)
}

\section{Ulicznica?}

Pierwszy druk wenecki ujrzał światło dzienne w 1469 r., a już w latach dziewięćdziesiątych tego stulecia książka stała się widoczna, wszechobecna wręcz w pejzażu Miasta nad Laguną ${ }^{1}$. Mówią o tym tak świadectwa przyjezdnych, jak dokumenty zachowane w weneckim archiwum ${ }^{2}$. Obok książek erudycyjnych łacińskich i greckich, teologicznych i uczonych łacińskich i in volgare, tych przeznaczonych niewatpliwie dla czytelnika wykształconego, pojawia się obieg ,średni”’3. Stosunkowo szybko, wraz z początkiem nowego stulecia, zaczynają też krążyć książki przeznaczone do użytku codziennego. (Świadomie nie używam tutaj terminu „książki popularne".)

Miejsca, w których odbywał się handel książkami drukowanymi, w dużym stopniu i w naturalny niejako sposób pozostawały te same, co uprzednio dla książki rękopiśmiennej. To most Rialto i jego okolice, plac San Marco, sąsiedztwo kościoła Santa Maria Formosa - miejsca

${ }^{1}$ Były to Epistolae ad familiares Cycerona, wydane przez Johannesa da Spira (GW 6800; 6801).

${ }^{2}$ Por. Rosa Salzberg, 'Per le Piaze \& Sopra il Ponte': Reconstructing the Geography of Popular Print in Sixteenth-Century Venice, [w:] Geographies of the Book, red. Miles Ogborn, Charles W. J. Withers, Farnham [England] - Burlington [USA, VT] 2010, s. 114-116. Por. też Neri Pozza, La prima diffusione della stampa nel Veneto, [w:] Il libro a stampa. I primordi, red. Marco Santoro, wyd. II, Napoli 1990, s. 281-285. Zob. też Amedeo Quondam, La letteratura in tipografia, [w:] Letteratura italiana, t. 2: Produzione e consumo, red. Alberto Asor Rosa, Torino 1983, s. 573-578.

${ }^{3}$ Por. Rudolph Hirsch, Stampa e lettura fra il 1450 e il 1550, [w:] Libri, editori e pubblico nell'Europa moderna. Guida storica e critica, red. Armando Petrucci, Roma 2003 (I wyd. 1977), s. 10-11, 17-19 i 40; Claudia di Filippo Bareggi, Il mestiere di scrivere: lavoro intellettuale e mercato librario a Venezia nel Cinquecento, Roma 1988, s. 54-56; Carl Bühler, Scribi e manoscritti nel Quattrocento europeo, [w:] Libri, scrittura e pubblico nel Rinascimento, red. A. Petrucci, Roma-Bari 1979, s. 50-55. Por. też Guy Demerson, Livres populaires du XVIe siècle. Répertoire Sud-Est de la France, Paris 1986. 
centralne, czasem, jak w przypadku mostu Rialto, wręcz strategiczne dla całej Wenecji - każdy w zasadzie mieszkaniec i przybysz musiał wówczas (jak i dzisiaj) tamtędy przejść. Przez pewien czas oba rodzaje książek sprzedawane były równolegle czy wręcz jednocześnie, obok siebie - zgodnie $z$ istniejącym popytem na oba ich rodzaje ${ }^{4}$. Nawet jeśli uliczną sprzedaż książek i druków ulotnych zwykło się uważać za stosunkowo mało znaczącą ilościowo, to sama jej obecność na ulicach, kramach, targach sprawia wrażenie, że książka jest dosłownie wszędzie. Wrażenie to wpływa na tradycyjny obraz obiegu książki. Wychodząc na ulice, książka ukazuje równocześnie swe powinowactwa z codziennością: z ulica jako miejscem zakupów, politycznej - szeptanej albo wykrzykiwanej - propagandy, przestrzenią dla procesji, pogrzebów, terenem zawierania podejrzanych znajomości, wabienia kurtyzan, miejscem nadziei, miejscem ostentacji, gdzie pokazuje się swoje bogactwo i pozycję, ale także miejscem, gdzie się żebrze i kradnie, a wieczorami terenem niebezpiecznym. Ulicami poruszają się wszyscy - nawet w pociętej siatką kanałów Wenecji nie sposób zupełnie ominąc ulic. Przestrzeń, w której mieszają się wszystkie stany, jest też przestrzenią szczególnie szybko zawłaszczaną przez nowoczesność - w naszym wypadku przez książkę drukowaną właśnie ${ }^{5}$.

Tutaj też następuje szczególne zaburzenie sposobu odbioru książki, postrzegania jej już nie jako przedmiotu wyjątkowego, dostępnego tylko uprzywilejowanym wybrańcom, drogiego, do kupienia tylko w wyspecjalizowanych sklepach $\mathrm{w}$ eleganckich dzielnicach... ${ }^{6}$ Pojawienie się, zadomowienie książki drukowanej $\mathrm{w}$ obiegu handlowym $\mathrm{z}$ jednej strony, a intelektualnym, czytelniczym - z drugiej, doprowadziło w konsekwencji do pewnego wymieszania poziomów odbioru. Książka przeznaczona do użytku codziennego i ku sprawom codziennym zwrócona pozwala doskonale prześledzić to rozchwianie ${ }^{7}$. Ulica, plac miej-

\footnotetext{
${ }^{4} \mathrm{Na}$ temat osiedlania się drukarzy i umieszczania przez nich warsztatów i sklepów oraz stoisk z książkami w kolejnych dzielnicach miasta: Frezzaria, San Moisè, Castello patrz R. Salzberg, dz. cyt., s. 116-120. Zamieszkiwali tam zarówno wydawcy uznani, z Gabrielem Giolito włącznie, jak i skromniejsi, tak ambicjami, jak rozmiarami produkcji.

${ }^{5}$ Literatura na temat ,życia ulicy" w okresie renesansu i wczesnej nowożytności stała się w ostatnich latach niezwykle bogata; patrz Fabrizio Nevola, Street Life in Early Modern Europe, „Renaissance Quarterly”, 66(4):2013, s. 1332-1345.

${ }^{6}$ Zob. A. Petrucci, Alle origini del libro moderno. Libri da banco, libri da mano libri da bisaccia, [w:] Libri, scrittura e pubblico..., s. 140; Angela Nuovo, Il commercio librario nell'Italia del Rinascimento, Milano 2003, s. 108-110; R. Salzberg, dz. cyt., s. $12-13$.

${ }^{7}$ Por. artykuły A. Petrucciego zamieszczone w Letteratura italiana... (Il libro manoscritto, s. 522-524; Le biblioteche antiche, s. 543-546) oraz Alle origini del libro..., s. $142-143,146-147$.
} 
ski były także sceną przenikania się tych dwóch przestrzeni, kiedy wykorzystywano je jako miejsca spektaklu dla śpiewaka, aktora, akrobaty, recytatora, dla tego, kto wykrzykiwał pamflety ${ }^{8}$. Wśród masy druków ukazujących się ówcześnie w Wenecji, stanowiących ponad $40 \%$ książek wydawanych na Półwyspie Apenińskim, te określane zwykle jako „popularne” (przy całej ambiwalencji i nieprecyzyjności, a nawet dyskusyjności tego sformułowania) zajmowały wiele miejsca ${ }^{9}$.

Niniejsze rozważania wymagają dokonania dodatkowych rozróżnień, już wśród samych wydawnictw popularnych. Nie będę bowiem zajmować się tu ani książkami religijnymi - dewocyjnymi, ani literaturą służącą rozrywce, ani drukami ulotnymi: przeobfitą produkcją pamfletów politycznych czy kart reklamowych, towarzyszących wszak życiu powszedniemu ówczesnych ludzi ${ }^{10}$. Jeśli trudno jest dzisiaj o nich mówić, to nie tylko dlatego, że zmieniła się nasza codzienność i potrzebujemy innych ,,poradników”, innych instrukcji wykonywania zwyczajnych zajęć. Dzieje się tak przede wszystkim dlatego, że publikacje tego typu długo pozostawały poza orbita zainteresowań badaczy. Status książek używanych na co dzień nie skłaniał bowiem do okazywania im szczególnego szacunku, mimo że fakt szerokiego wykorzystywania tych tekstów świadczy o doskonałej znajomości potrzeb czytelników i o umiejętności szybkiej reakcji na nie ze strony autorów i wydawców.

Potrafimy powiedzieć, kto miał takie wyczucie, kto tak znakomicie rozumiał czytelnika (właściwiej byłoby już teraz powiedzieć: czytel-

${ }^{8}$ Zob. R. Salzberg, dz. cyt., s. $14-19$.

${ }^{9}$ Zob. A. Quondam, dz. cyt., s. 584, 587. Drugi co do wielkości ośrodek na Półwyspie Apenińskim, Rzym, produkował - w zależności od okresu - od 4 do 14\% ogólnej liczby książek, a kolejny - Florencja - od 5 do 12\%. Por. R. Salzberg, dz. cyt., s. 111112 (łącznie z przyp. 1-7); Paul F. Grendler, Il libro popolare nel Cinquecento, [w:] La stampa in Italia nel Cinquecento. Atti del Convegno, Roma 17-21.10.1989, red. Marco Santoro, Roma 1992, s. 212-213, 232-234 (łącznie z przyp. 2, 58, 59); tenże, Form and Function in Italian Renaissance Popular Books, „Renaissance Quarterly”, 46(3):1993, s. 452-454. Zdaniem tego autora kryteria pozwalające na wyróżnienie książki „popularnej” odnoszą się głównie do jej wyglądu, tj. formatu, kroju czcionki, obecności ilustracji, mniej zaś - do tematyki i istotnej zawartości.

${ }^{10} \mathrm{Na}$ temat religijnej literatury popularnej patrz tamże, w przypisie. Zob. także Joanna Pietrzak-Thébault, Między kosmiczna harmoniq a "malhora di ogni di" - malżeństwo w oczach włoskich autorów XVI wieku, [w:] Glos kobiecy, głos męski. Obcy $w$ dawnych literaturach romańskich, red. Maja Pawłowska, Wrocław 2004, s. 75-89 i taż, Pisane na wodzie, rzucone na wiatr. Ulotne druki - skarb dla biblioteki, wyzwanie dla badacza, [w:] Dawne literatury romańskie. Żywioly, temperamenty, charaktery, red. Maciej Abramowicz, Paweł Matyjaszewski, Lublin 2011, s. 49-58. 
niczkę $\left.{ }^{11}\right)$. To bynajmniej nie autorzy anonimowi, jak skłonni bylibyśmy sądzić w pierwszym odruchu, i bynajmniej nie najpośledniejsi wydawcy. Co ciekawe, w strategii edytorskiej druki te odgrywały zwykle bardzo istotną rolę. Ich publikacja nie była wynikiem przypadku, lecz świadomej decyzji. Szybka sprzedaż tego typu książek miała bowiem niejednokrotnie wspomagać finansowanie pozycji droższych, o charakterze erudycyjnym, rozchodzących się wolniej, za to zapewniających wydawnictwu prestiż i nieprzerwaną obecność na rynku. Taką praktykę stosowano m.in. w oficynie rodziny Vavassore, która kilkakrotnie opublikowała zielnik a zarazem receptariusz mogący służyć jako teoretyczna podstawa do skompletowania domowej apteczki. Na pierwszy rzut oka najprościej byłoby jednoznacznie zadekretować, iż taki druk adresowano do czytelnika najmniej wykształconego i najmniej wymagającego, potrzebującego porady w sprawach najprostszych i szukającego jej w książce właśnie ${ }^{12}$. We wstępie do Herbolario volgare czytamy jednak, że ponieważ leki w aptece są drogie, lepiej kupić książkę i samemu fabrykować niezbędne specyfiki ${ }^{13}$. Zapewne nie jest to jedynie chwyt reklamowy, lecz także odzwierciedlenie ówczesnych stosunków cen. Inne oficyny natomiast, jak choćby ta należąca do Niccoló Zoppina najwyraźniej czułe na nowe tendencje - świadomie decydowały się na wydawanie wyłącznie takich pozycji ${ }^{14}$. Zoppino zakładał, że jego produkcja znajdzie odbiorców nie tylko wśród tych 33\% mężczyzn i 13\% kobiet, którzy potrafili wówczas czytać (tak przynajmniej przedstawiają się statystyki, jeśli chodzi o Wenecję) ${ }^{15}$. Był przekonany, że grono zainteresowanych wzrośnie...

Przypatrzmy się zatem z bliska kilku weneckim książkom tamtego czasu, zobaczmy, do kogo poszły one „na służbę”.

\footnotetext{
${ }^{11}$ Na temat kobiecej lektury por. niżej, s. 40-41 oraz R. Salzberg, dz. cyt., s. 118 (łącznie z przyp. 26).

${ }^{12}$ Patrz J. Pietrzak-Thébault, „Herbolario volgare” - między lekarska ambicja a zachwytem, „Kwartalnik Historii Nauki i Techniki”, 52(1):2007, s.160. Tam zob. też szerzej na temat zielników (s.153-155, 158-159).

13 „Per molti poveri quali per incomodità de denari restano de andare ala bodega, \& kuesto perche le cose necessarie al Corpo infermo, \& cose semlplice come composte se comprano con molti denari" - Herbolario volgare, Venezia 1534, k. 2r - Bibliothèque Sainte Geneviève, Paris, S 8243 inv 2114).

${ }^{14}$ Zob. Lorenzo Baldacchini, Chi ha paura di Nicoló Zoppino? Ovvero: La bibliologia è una 'coraggiosa' disciplina'?, „Bibliotheca. Rivista di studi bibliografici”, 1:(2002, s. $187-191$.

15 Zob. P.F. Grendler, Schooling in Western Europe, „Renaissance Quarterly”, 43:1990, s. 779; R. Hirsch, dz. cyt., s. 15-17.
} 


\section{Warząchiew}

Epulario $^{16}$ to niewątpliwie książka użytkowa i ciesząca się popularnoś-cią. Dziełko na pograniczu traktatu i książki kucharskiej pojmowanej jako spis przepisów zaliczane jest zwykle do gatunku receptariuszy. Notuje się obecnie ponad 50 wydań tej pozycji, począwszy od roku 1516 aż po drugą połowę XVII stulecia. Najwyraźniej jest to najpopularniejsza książka kucharska napisana w języku wernakularnym; doczekała się ona także tłumaczenia na język angielski (opublikowanego w Londynie w 1598 roku). Wszystkie edycje mają skromną szatę graficzną, ukazują się w formacie $8^{\circ}$ lub (dużo rzadziej) $-12^{\circ 17}$. Jest to jednak książka o erudycyjnym rodowodzie. Źródeł przynajmniej części przepisów specjaliści dopatrują się $\mathrm{w}$ recepturach Maestra Martina z Como - słynnego XV-wiecznego kucharza patriarchy Akwilei. Z książką wiążą się liczne tajemnice - dotyczące tak samego jej autorstwa, źródeł, jak i odbiorców. W zakresie dawnych praktyk gotowania jest na tyle instruktywna, że może wydać się inspirująca i dzisiaj... Choć ma formę receptariusza, stosowanego chętnie także w innych dziedzinach domowej wiedzy (kosmetologia, leki), to nie wydaje się, by była przeznaczona dla jednego czytelnika. Publikacja ta z pewnością różni się od inspirującej ją Libro de arte coquinaria Mistrza Marcina ${ }^{18} \mathrm{i}$ wykorzystywana może być na wiele sposobów. Ciekawość każe nam zajrzeć do środka. Klasyfikacja potraw nie opiera się na jednorodnych kryteriach i zdradza zależność od wielu źródeł. Mamy zatem do czynienia zarówno z podziałem zależnie od podstawowego składnika (mięso, drób, ryby, pastelle, czyli ciasta), jak i według sposobu przygotowywania (pieczenie lub gotowanie). Ważny jest podział na potrawy ,tłuste” i postne. Nierzadko jedno danie ma dwie wersje, może

${ }^{16}$ Epulario quale tratta del modo de cucinare ogni carne ucelli pesci de ogni sorte e fare sapori; torte; e pastelli al modo de tutte le Provincie, Venetia 1549.

17 Zob. Georges Vicaire, Bibliographie Gastronomique, Paris 1890, s. 759-717; Katherine Golden Bitting, Gastronomic Bibliography, San Francisco 1939, s. 408; Catalogo del Fondo Italiano e Latino delle opere di gastronomia, secoli XIV-XIX, red. Orazio Bagnasco, Sorengo 1994, t. 2, s. 1477-1478; Henry Notaker, Printed Cookbooks in Europe, 1470-1700, New Castle-Houten 2010, s. 343-344. O książce tej wspominają także starsze opracowania bibliograficzne o charakterze ogólnym, które - choć dalekie są od wymieniania wszystkich wydań dziełka - podają często obszerne i interesujące opisy poszczególnych edycji, a nawet egzemplarzy. Por. Jacques-Charles Brunet, Manuel du libraire et de l'amateur de livres, Paris 1860-1865, t. IV, s. 1393. Victor Masséna Essling, Etudes sur l'art de la gravure sur bois à Venise. Les livres à Figures Vénitiens de la fin du XV́ siècle et du commencement du XVI , Florence-Paris 1907-1914, (poz. 1924-1928), Partie seconde, t. 1, s. 230-332; Max Sander, Le livre à figures italien depuis 1477 jusqu'à 1530. Essai de sa bibliographie et de son histoire, Milano 1942, (poz. 6.600-6.604), t. 3, s. 1145-1146.

${ }^{18}$ Libro de arte coquinaria ukazało się w formie cyfrowej w opracowaniu Emilia Faccioli - zob. Maestro Martino, Libro de arte coquinaria, 2004 [http://www.uni-giessen.de/gloning/tx/martino2]. 
zostać przygotowane na dwa różne sposoby, zależnie od okresu w roku liturgicznym. Wysoka frekwencja przepisów tego typu wyraźnie wskazuje na genezę dziełka - receptariusz powstał w kuchni kościelnego dostojnika. Nie wprowadzono natomiast podziału na dania główne i desery. Wiele potraw można przyrządzić „,na słodko lub słono”, zmieniając tym samym ich charakter. Oba smaki mieszają się zresztą, zgodnie z ówczesną normą kulinarna, bardzo często. Poradom dotyczącym przyprawiania niejednokrotnie towarzyszy wzmianka: „tak, jak lubi twój pan” (,come piace al tuo patrone”), świadcząca o tym, że użytkownikiem książki najwyraźniej miał być sługakucharz. Ostateczny wybór w kwestii przyprawiania dań traktat pozostawia wykonawcy, zaznaczając jedynie, że dodać trzeba herbe - zioła. Gusta kulinarne panów bywały różne, skoro obok przepisów na potrawy zwyczajne, łatwe do wykonania - pieczoną na ruszcie sarnę czy pieczone koźlę, znajdujemy rybę przyrządzaną jednocześnie na trzy sposoby, podaną na jednym półmisku, czy pawia ozdobionego piórami i wyglądającego jak żywy. Receptury wielokrotnie wykorzystuja jedną z kilku podstawowych „baz”jedną z nich jest biancomangiare (rodzaj migdałowo-mlecznej zupy), druga - brodo (bulion). Nie ma tutaj miejsca na bardziej szczegółowe omawianie tajemnic XVI-wiecznej kuchni, lecz trzeba zapytać, czy występowanie potraw najprostszych obok najbardziej wyrafinowanych było jej stała cecha, czy też raczej stanowi o tajemniczym (również dla dzisiejszych odbiorców) charakterze tej publikacji. Czy skromny egzemplarz nie mógł służyć także jedynie do czytania o skomplikowanych daniach - znamy to zjawisko z autopsji - nieraz przeglądamy przecież egzotyczne książki kucharskie czy przepisy $\mathrm{w}$ ilustrowanych pismach dla samej przyjemności lektury (oraz oglądania fotografii) i nie mamy wcale intencji, by faktycznie wypróbować receptury w naszej kuchni... Prezentowane przypuszczenia wydają się tym bardziej prawdopodobne, że w niektórych z wydań omawianego dziełka pomijano część poświęconą nakrywaniu do stołu i urządzaniu bankietów, a w zamian dodawano wskazówki co do prowadzenia domu, czasem wręcz podstawowe. Były to zatem rady dotyczące zapobiegania kipieniu mleka, przechowywania zapasów, sporządzania prostych leków na codzienne dolegliwości, a nawet... produkowania wina z octu (jednak wyłącznie, jak głosi książka, w razie nagłej potrzeby). Dla badaczy kultury oraz zwyczajów czytelniczych i kulinarnych Epulario pozostaje źródłem bezcennym ${ }^{19}$. Wbrew

${ }^{19}$ Zob. Odile Redon, Françoise Sabban, Silvano Serventi, La gastronomie au Moyen Age: 150 recettes de France et d'Italie, Paris 1991, p. 15-16; Mary Ella Milham, Platina and Papal Politics, [w:] Du Manuscrit á la table. Essaies sur la cuisine du Moyen Age et répertoire des manuscits médiévaux contenant des recettes culinaires, in dir. Carole Lambert, Montréal-Paris 1992, p. 8. 
pozorom, dzieje recepcji tej pozycji to zagadnienie interesujące także dla wiedzy o humanistycznych księgozbiorach - publikacje tego typu stanowiły bowiem ich integralną część, podobnie jak poradniki zielarskie czy $\mathrm{z}$ zakresu prowadzenia gospodarstwa domowego ${ }^{20}$.

\section{Mydło i perfuma}

Otwarcie niepozornej, wydawałoby się, książeczki zatytułowanej I Secreti [...], czyli Sekrety czy może Tajemnice pani Izabeli Cortese, w których zawieraja sie sprawy dotyczace mineratów, medycyny, rzeczy wytworzonych[?] i alchemii oraz wiele ze sztuki perfumeryjnej, przynależne każdej wielkiej damie, wraz z innymi najprzedniejszymi sekretami dołaczonymi autorstwa Izabelli Cortese okazało się początkiem fascynującej przygody $^{21}$. Między rokiem pierwszego wydania - 1561 a 1677, kiedy dzieło to opublikowano po raz siedemnasty i ostatni, upłynęło przeszło 100 lat. Wszystkie edycje ukazywały się w Wenecji. Wszystkie wychodziły w tym samym poręcznym, zdradzającym przeznaczenie dla mniej zamożnego czytelnika, formacie, ale w różnych oficynach. Nie było bowiem ówcześnie wydawców specjalizujących się wyłącznie w książce użytkowej, medycznej, farmaceutycznej. Nowe edycje ukazywały się regularnie, $w$ odstępach kilku lat, co świadczy o niesłabnącym popycie na tę pozycję. Do wydań włoskich dorzucić musimy jeszcze dwa thumaczenia na język niemiecki (opublikowane trzykrotnie: w Hamburgu w 1592 i 1596 r. i we Frankfurcie w tymże 1596 roku).

Ślady tamtej popularności odnaleźć możemy także i dzisiaj - w postaci bardzo licznie zachowanych egzemplarzy książki, zarówno w bibliotekach włoskich (gdzie doliczono się aż 58 tomów), jak polskich

${ }^{20}$ Egzemplarz Epulario figurujący w katalogu zbiorów Biblioteki PAN w Gdańsku, został, niestety, zagubiony. Tom należał do kolekcji markiza Bonifacio d'Oria. Szerzej na temat tego księgozbioru zob. J. Pietrzak-Thébault, Les perles de la Baltique, [w:] Autour des 'livres que l'on n'a pas lus', red. Tomasz Swoboda, Ewa Wierzbowska, Olga Wrońska, Sopot 2011, s. 179-188. Ostatnio o tej kolekcji pisała Urszula Szybowska (Zapiski pożeracza ksiag. O rodzajach i funkcjach marginaliów na podstawie notatek Jana Bernarda Bonifiacia, Pruszcz Gdański 2012). Drugi, a obecnie jedyny dostępny czytelnikom w Polsce, egzemplarz dziełka znajduje się w Bibliotece Jagiellońskiej (sygn. Gospod. 348) - jest to wydanie Spinedy z 1598 roku.

${ }_{21}$ Zob. André Hahn, Paule Dumaître, Histoire de la medicine et du livre medical, Paris 1962, s. 92, 98. Ewa Bartochowska, Ksiega czarownicy czyli kilka uwag o I Secreti de la Signora Isabella Cortese..., „Roczniki Biblioteczne”, 51:2007, s. 127-143. Patrz też J. Pietrzak-Thébault, Isabella Cortese - czyli alchemia kobiecej urody, „Colloquia Litteraria”, 6/7:2009; taż, Strzė̇ się dżumy, odganiaj złe humory - czyli przepisy na leki $w$, księdze czarownicy” - I Secreti de la Signora Isabella Cortese... jako podręcznik domowej farmacji, [w:] Pamiętnik XVI Sympozjum Historii Farmacji, Krasiczyn 2007, Rzeszów 2007, s. 153-164. 
$(9 \text { pozycji })^{22}$. O ile stosunkowo dużo możemy więc powiedzieć o edytorskich dziejach utworu, o tyle o jego autorce nie wiemy, niestety, zgoła nic. Nawet badania prowadzone współcześnie przy okazji edycji Sekretów opublikowanej w Neapolu w 1999 r. nie przyniosły bliższych ustaleń $^{23}$, choć zazwyczaj o kobietach autorkach dzieł literackich czy naukowych wiemy sporo, jako o osobach nieprzeciętnych i fascynujących jeszcze po upływie wielu wieków ${ }^{24}$. Niemal współczesny Isabeli Tommaso Garzoni, który w swoistej encyklopedii, (ówcześnie często wydawanej, a dzisiaj stanowiącej niezwykle cenne źródło informacji dla badaczy epoki) opisuje ,wszystkie zawody świata”, wspomina naszą bohaterkę dwukrotnie, umieszczając ją wśród „mistrzów sekretnej nauki” ${ }^{25}$. Zarazem pisze on, że nazwisko „Cortese” to pseudonim.

${ }^{22}$ Dzieło to pojawia się w katalogach aż sześciu rodzimych bibliotek. W BUW znajdujemy wydanie Bariletta z 1574 r. (najczęściej zreszta obecne w polskich zbiorach), w BUWr przechowywane jest drugie wydanie Bariletta z 1565 roku, w BJ zaś egzemplarze: Bariletta z 1574, Bonibellego z 1595 i Spinedy z 1614 roku. W Gdańsku, w Bibliotece PAN-u, mamy jeden egzemplarz edycji Cornettiego z 1592 oraz jeden wersji niemieckiej Bindera z 1592 roku. Dwa kolejne egzemplarze niemieckojęzyczne figurują w zbiorach bibliotek UŁ oraz UMK w Toruniu. Do tych dziewięciu egzemplarzy, pochodzących z czterech różnych edycji (w tym trzech egzemplarzy niemieckich), będących w posiadaniu polskich bibliotek dorzucić należy ponadto jeden egzemplarz wydania Tivanniego z 1677 roku, znajdujący się w zbiorach piszącej te słowa.

${ }^{23}$ Anna Santoro, która przygotowała w 1999 roku reedycję I Secreti... finansowana przez Comune di Napoli, uważa, że rodzina Cortese mogła pochodzić z Rzymu, Wenecji lub Florencji, a miejsce wydania dzieła o niczym nie przesądza. Z kolei Massimo Marra przypomina Johna Fergusona, który w swojej Bibliotheca Chemica z 1906 r. wspominał naszą autorkę, pisząc, że nazywana jest: Cortesa, Cortese, Cortesi, lecz poza tym nigdzie nie spotkał się z żadną wzmianką na jej temat. Zob. Massimo Marra, Introduzione ai 'Secreti di Isabella Cortese 'http://www.levity.com/alchemy/isabella. html [6 05 2014].

${ }^{24}$ Zgodnie z ustaleniami Petera Burke'a (La Renaissance en Italie: art, culture, société, Paris 1991), spod piór kobiecych wyszło 158 utworów literackich i 38 określanych jako „naukowe”. Stanowi to najwyżej kilka procent całej produkcji wydawniczej, którą najnowsze obliczenia szacują na ok. 6000 wydań w I poł. stulecia i $7420 \mathrm{w}$ II, z czego 556 stanowiły edycje dzieł powstałych współcześnie.

${ }_{25}$ Tommaso Garzoni, La piazza universale di tutte le professioni del mondo, Venezia 1585 (cyt. za wydaniem: T. Garzoni, La piazza universale ..., a cura di Giovanni Battista Bronzini Firenze 1996, s. 243, 795). Isabella Cortese sąsiaduje tu z postaciami takimi jak: Pliniusz, Albert Wielki, Roger Bacon, Hieronim Sardano, Giovanni Battista della Porta, Alessio Piemontese, Hieronim Ruscello (to też pseudonim!), Leonardo Fioravanti, Gabriele Falloppio, Antonio Mizaldo, Levinio Lemnio, Giacobo Wechero, Pietro Bairo, Giovanni Battista Zapata, Timoteo Rossello, Giovanni Ventura Rosetti i w końcu - Paracelsus. Cortese wymienia się także wśród mistrzów produkujących perfumy. Obraz farmaceutów, zielarzy, alchemików w książce Garzoniego mógłby zresztą z powodzeniem stanowić odrębny temat badawczy... Por. William Eamon, Science and popular culture in Sixteenth Century Italy: the „Professors of Secrets” and their books, „The Sixteenth Century Journal”, 16(4):1985, s. 474. 
Czym jest owa tajemnicza, chciałoby się powiedzieć „księga”, tymczasem trzeba użyć określenia „książeczka”, typowe włoskie ricettario spis przepisów i recept, uporządkowany tematycznie? Ricettaria - dzieła użytkowe, ale nierzadko upowszechniające przy tym wcale głęboką wiedzę farmaceutyczna, kosmetologiczna, z zakresu domowej medycyny, prowadzenia gospodarstwa domowego i kuchni, nie były bynajmniej edycjami mało starannymi ${ }^{26}$. I nawet jeśli zdarzało się wydawcy użyć tańszej, nieco niemodnej czcionki, to wszelkich procedur wydawniczych przestrzegano nader starannie, pamiętano o dokładnym spisie treści, nierzadko także o indeksie alfabetycznym, elementach zdobniczych i ilustracjach.

Książka ta nie jest bynajmniej publikacją wyjątkowa, lecz jedną z wielu, co najmniej dziesięciu, które ukazały się w XVI stuleciu na włoskim rynku. Cieszyły się one popularnością mierzoną 240 wydaniami włoskimi i licznymi tłumaczeniami na wiele języków europejskich ${ }^{27}$. Autorzy tych zbiorków chlubili się nie tyle oryginalnym wkładem do skarbnicy wiedzy, ile trudem zebrania, spisania i przekazania czytelnikom istniejących już i krążących przepisów. Watpliwości co do autorstwa I Secreti wzmaga również fakt, że wiele receptur w książce Cortese jest niemal identycznych z przepisami ze zbioru Della summa de' secreti universali Timotea Rosella z 1559 roku. Oba dziełka wydał Bariletto, w obu pojawia się odwołanie do patrona Maria Chaboga, archidiakona Ragusy (Dubrownik) ${ }^{28}$. Formuła ta, nawet jeśli tekst pisany był językiem monotonnym i płaskim, gęsto usianym określeniami technicznymi, zapewniała jednak utworowi, co już zdążyliśmy zauważyć, sukces wydawniczy.

Interesująca nas pozycja podzielona jest na 4 księgi, z których każda zawiera receptury mniej więcej podobnego rodzaju: 1 - prezentuje sposoby produkcji leków, 2 - opisuje eksperymenty alchemiczne (to część zdecydowanie najbardziej tajemnicza, znajdziemy tu m.in. przepisy na atrament sympatyczny czy na uszlachetnienie metali), 3 - omawia ,chemię gospodarstwa domowego" (np. kleje do mozaiki, odplamiacze, farby - także do włosów, środki do prania i czyszczenia), 4 - najobfitsza pod względem liczby przepisów, dotyczy kosmetyków i wód perfumowanych.

${ }^{26} \mathrm{O}$ miejscu alchemii w kulturze i piśmiennictwie europejskiego odrodzenia zob. R. Bugaj, Hermetyzm, Wrocław 1991. s. 194-200. Por. też J. Pietrzak-Thébault, Isabella Cortese-czyli..., dz. cyt.

${ }^{27}$ Zob. William Eamon, Science and the Secrets of Nature. Books of Secrets in Medieval and Early Modern Culture, Princeton [New Jersey] 1996, s. 134-167.

${ }^{28}$ Zob. Jo Wheeler, Renaissance Secrets. Recipes \& Formulas, London 2009, s. 37. Por. Ernesto Riva, La cosmesi a Venezia nel XVI secolo e i segreti di Isabella Cortese, "Natural", 7:2006, s. 39-45. 
Choć tajemnym recepturom poświęcona jest szczególnie księga druga, to alchemiczny sposób pojmowania przyrody przenika całość ricettaria. Historycy alchemii twierdza, że opisywane przez Izabelę procedury świadczą o jej dużej wiedzy w tej dziedzinie i o tym, że osobiście przeprowadzała eksperymenty ${ }^{29}$. Ksiażza wykazuje jednak dziwne pomieszanie rejestrów. Zakres tematyki sięga od hermetycznej, nieledwie naukowej, alchemii po prezentację farby do włosów, od lekarstwa na „chorobę francuską", czyli syfilis, po środek na pozbywanie się plam, od mydła różanego po antidotum na truciznę. Nie znajdziemy jednak u Isabeli remediów na choroby codzienne i banalne: przeziębienia, bóle głowy, uszu i gardła, kaszel itp. Odpowiada to obrazowi dzieła jako utworu wszechstronnego, niemieszczącego się jednak w kategorii domowych poradników, nie mającego na celu przekazania wiedzy dotyczącej prowadzenia gospodarstwa domowego. Jakiemu zatem i czy jednemu czytelnikowi miały służyć te praktyczne rady? Raz jeszcze stajemy wobec „rozchwianego”, niepewnego obrazu odbiorcy - czytelnika i czytelniczki.

To, co jest nam jednak potrzebne, to nie lektura wyrywkowa, nastawiona na wychwytywanie szczególnie zabawnych fragmentów, lecz uważne przestudiowanie całego dzieła. Współcześnie nierzadko mamy kłopoty z odczytaniem wszystkich podawanych przez autorkę uwag, a jeszcze częściej - trudność w odtworzeniu dokładnego składu wielu mikstur. Nazwy roślin potrafią znacznie różnić się między sobą i w okresie, kiedy nie istniała jeszcze ustalona systematyka, nawet użycie łacińskiego określenia nie musiało gwarantować, że w dwóch różnych krajach, regionach, a nawet recepturach, które mogły wszak pochodzić z odmiennych źródeł, chodziło o ten sam składnik. Inne przepisy moga natomiast z powodzeniem być wykorzystane - o ile nie zniechęci nas długa i uciążliwa procedura... Pamiętajmy o jeszcze jednym problemie związanym z informacjami podlegającymi formom długotrwałego przekazu. Warto posłuchać his-

\footnotetext{
${ }^{29} \mathrm{Na}$ temat natury alchemii i jej miejsca w świecie w czasie, gdy Isabella pisała swój traktat, zob. też: William Eamon, Alchemy in Popular Culture: Leonardo Fioravanti and the Search for the Philosopher's Stone, „Early Science and Medicine”, 5(2):2000, s. 196-213; Chiara Crisciani, L'alchimia dal Medioevo al Rinascimento: scientia o ars?, [w:] Il Rinascimento italiano e l'Europa, a cura di Antonio Clericuzio, Germana Ernst, t. 5: Le scienze, [Treviso], [Costabissara (Vincenza)] 2008, s. 111-128; Perrone Compagni, Maritare il mondo. Magia naturale ed ermetismo, [w:] Il Rinascimento italiano..., s. 95-110; Michela Pereira, Alchemy and use of vernaculars languages in the Late Middle Ages, "Speculum", 74(2):1999, s. 336-356. Szczegółowe opracowanie tego tematu na gruncie polskim - zob. Ewa Bartochowska, Sekrety Isabelli Cortese - alchemia czy magia, [w:] Czary, alchemia, opętanie w kulturze na przestrzeni stuleci. Studia przypadków, red. J. Pietrzak-Thébault, Łukasz Cybulski (w druku). Powyższe wskazówki bibliograficzne zawdzięczam p. Ewie Bartochowskiej, której pragnę tutaj podziękować za udostępnienie mi ich, zanim jej artykuł zdążył ukazać się drukiem.
} 
toryków książki drukowanej, którzy przestrzegają przed „niemożliwymi do zrealizowania receptami zawartymi w traktatach medycznych" i radzą zachować nadzieję, że tymi przepisami ,zaczytywali się [...] w większym stopniu poeci niż lekarze" ${ }^{30}$. Może uzasadnione staje się wobec tego pytanie, czy warto wkładać niemały przecież trud w rozszyfrowywanie dawnych włoskich receptur. A jeśli już - to w jaki sposób to robić?

Od pewnego czasu pojawiają się informacje o odkrywaniu na nowo dzieła Isabeli Cortese, a nawet o swoistej nim fascynacji. Wszystkie one potwierdzają przekonanie, że nie chodzi tutaj jedynie o odkurzanie, zabawnej skądinąd, ciekawostki wydawniczej, ale o szansę uchwycenia ważnego ogniwa między filozoficzną i literacką wizją świata a praktycznym jego kształtowaniem. Ogniwa świadczącego także o większej, niż zwykliśmy sądzić, jedności ówczesnego świata.

\section{Igła}

O, Panie i Panny, co haftować pragniecie,

Pójdźcie do mego źródła, wieczną sławę zyszczecie. ${ }^{31}$

Takimi słowy zachęcał czytelniczki pewien z weneckich wzorników haftów, wydany w połowie XVI wieku. Był jednym z wielu, bowiem zbiorki zawierające modele haftów należały do najpopularniejszych ówczesnych publikacji, a Wenecja uchodziła $\mathrm{w}$ tej dziedzinie za autorytet. Wydawane jeszcze w XV wieku, cieszyły się niesłabnącą popularnością a modeli haftów i koronek dostarczali chętnie weneccy artyści - na co dzień przecież współpracownicy drukarskich oficyn. Nie powinno nas dziwić, że znajdujemy tu nazwiska wielkie, jak: Pollaiuolo, Sassetta, Bellini, Botticelli, Raffaellino da Garbo, skoro projekty te miały status zupełnie różny od naszych dzisiejszych, zresztą właściwie całkowicie zapomnianych, ,robótek”, a igłą parały się damy i panny wysoko urodzone.

${ }^{30}$, ,...] jeśli weźmiemy pod uwagę obniżenie się merytorycznej wartości tekstów przepisywanych przez stulecia, fałszywe lekarstwa i niemożliwe do zrealizowania recepty zawarte w traktatach medycznych, pozostaje nadzieja, że zaczytywali się nimi w większym stopniu poeci niż lekarze. Jeśli uwzględnić egzotyczne składniki wymieniane we wczesnych farmakopeach drukowanych, lepiej przypuścić, że niewielu aptekarzy próbowało na serio preparować leki według zawartych w nich recept, nawet jeśli byli skłonni gromadzić na półkach tajemnicze specyfiki na wypadek, gdyby nowa kampania reklamowa rozbudziła na nie popyt" - Elisabeth Eisenstein, Rewolucja Gutenberga, przekł. Henryk Hollender, Warszawa 2004, s. 79 [tyt. oryg. The printing press as an agent of change, I wyd. 1979].

${ }^{31}$ Libro secondo di bellissime e variate mostre intitulato Fior de gli Essempi, Giovanni Andrea Vavassore, Venezia 1545, k. [2r]: „Donne e donzelle che el cuscir seguite, / Per farvi eterne alla fonte venite". 
Była to też, jak pouczały ówczesne traktaty o wychowaniu, jedyna praca godna księżnych i monarchiń. I nie powinno też dziwić, że druk okazał się tak znakomitym i naturalnym sprzymierzeńcem modeli i wzorów: sprzyjały temu niedroga technika drzeworytowa i ksylograficzna, praktyka, by nie rzec - tradycja, weneckiej książki ilustrowanej.

W ciagu XVI stulecia ukazały się w Wenecji 134 wydania 52 różnych dziełek z tej dziedziny. Najpopularniejsze miewały po kilkanaście edycji, a tylko 20 wydanych zostało jeden jedyny raz $^{32}$. Ta liczba potwierdza zarówno techniczne możliwości weneckiego drukarstwa, jak i przeznaczenie większości tych edycji na eksport...33

W okresie największej popularności produkcją tą zajmowało się 20 weneckich oficyn, choć żadna z nich nie specjalizowała się wyłącznie w tej pracy. Tomiki $\mathrm{w}$ charakterystycznym poprzecznym formacie $4^{\circ}$, liczace od 16 do 35 kart, najczęściej zaś 24 , zawierały wzory koronek (igłowych, wykonywanych różnymi technikami) o zróżnicowanym stopniu trudności: dla początkujących lub o niezwykle skomplikowanych splotach, rozrysowane na pojedyncze ściegi albo, niewiele różniące się od obrazka, makatki ze scenkami o romansowej bądź mitologicznej tematyce (Orfeusz otoczony zwierzętami, grający na... violi d'amore), także modne arabeski i moreski. Zbiór drzeworytowych ilustracji zostaje zwykle poprzedzony kilkoma zdaniami lub wierszami wstępu, chwalącego zalety dziełka i sławiącego cnoty niewieście, wśród których zręczność i cierpliwość w posługiwaniu się igłą należały do najważniejszych.

Zresztą nie tylko kobiety były odbiorczyniami pięknych wzorników - na karcie tytułowej Esemplario di lavori widzimy i haftujących mężczyzn - było to zajęcie podobne do dzisiejszego hobby w rodzaju niedzielnego malowania... ${ }^{34}$ Krótkie teksty wprowadzające, pisane proza lub wierszem, adresowane są jednak zwykle do czytelniczek (choć nie mamy przecież do czynienia z książką do „czytania”, lecz do praktycz-

\footnotetext{
${ }^{32}$ Zob. Arthur Lotz, Bibliographie der Modelbücher. Beschreibendes Verzeichnis der Stick - und Spitzenmusterbücher des 16. und 17. Jahrhudrets, Stuttgart-London 1963 (reprint I wyd. z 1933 r.), s. 112-139, 145-185, 199-224, 227-331, 233-235. W tym samym czasie we Francji ukazało się ok. 50 wydań wzorników, w Niemczech - 63, w Anglii zaś zaledwie 6. Zob. też M. Sander, dz. cyt., p s. cyt.

${ }^{33} \mathrm{Na}$ temat weneckiego handlu książkami zob.: A. Nuovo, dz. cyt., passim, Amedeo Quondam, 'Mercanzia d'onore'/ 'Mercanzia d'utile'. Produzione libraria e lavoro intellettuale a Venezia nel Cinquecento, [w:] Libri, editori e pubblico..., dz. cyt., s. 51-104. Szerzej o obecności książki weneckiej we Francji zob. Annie Parent, Les métiers du livre à Paris au XVIe siècle (1535-1560), Geneve 1974, s. 95 i nn.

${ }^{34}$ Nicoló Zoppino zaś w Gli universali di tutti e bei disegni [...] pisze we wstępie, że jego książką cieszyć się winien: ,[...] piękny umysł ludzki, duch pielgrzymi, tak mężczyzny, jak kobiety" (,[...] un bello intelletto humano, un pellegrino ingegno, si de huomo come di Donna" - cyt. za: M. Sander, dz. cyt., t. 3, s. 1125.
} 
nego używania, wykorzystywania). Haftujące damy są szlachetne, cnotliwe, a sławę zyskują dzięki cierpliwości i zręczności palców, systematyczności i pilności. Tytuły zbiorków zachęcają do kupna, brzmią: Kwiat, Fontanna, Źródło, Korona, Zwierciadło, Ogród, Uczta, Skarbnica. We wstępach pojawiają się także praktyczne informacje na temat metody wykonywania poszczególnych prac - obok różnych ściegów hafciarskich zwracają uwagę koronki igłowe, tak wówczas modne, wykonywane $\mathrm{w}$ różnych technikach ${ }^{35}$. Niełatwo jest jednoznacznie ocenić, na ile codzienna kobieca praca $\mathrm{z}$ igłą w ręku miała wyłącznie charakter szlachetnej rozrywki (jednej z nielicznych dostępnych zresztą wówczas na co dzień „uczciwej” czy „godnej” kobiecie...), będącej równocześnie sposobem praktykowania cnoty, na ile zaś służyła również celom praktycznym: haftowaniu wyprawy ślubnej, która służyć miała pannie nierzadko przez resztę jej dorosłego życia... ${ }^{36}$

Na pewno jednak możemy potwierdzić inne, niezwykle interesujące, zastosowanie praktyki codziennego haftu. Liczne abecedariusze, obecne w wielu zbiorkach, dobitnie świadczą o wykorzystaniu tej aktywności do nauki... czytania. Wpływ na skuteczność metody miała już sama długotrwałość procesu - nad jedną literką młoda osoba spędzała długie godziny i, nawet gdyby nie chciała, kształt jej, dzięki systematycznym, celowym ruchom ręki, musiał pozostać w pamięci ${ }^{37}$.

${ }^{35}$ Nie znano wówczas jeszcze późniejszej i wyrabianej do dzisiaj koronki klockowej, której wykonywanie stało się zresztą domeną zawodowych koronczarek, a nie szlachetnych i bogatych dam i panien.

${ }^{36}$ Zob. Histoire des femmes en Occident, red. Georges Duby, Michelle Perrot, Paris 1991, t. 2, s. 153. O innym jeszcze, nieco zaskakującym, powiązaniu tych prac z poetycką działalnością kobiet tamtego czasu zob. J. Pietrzak-Thébault, , [...] e 'l mio cantar $e$ "l mio scriver in carte". scrittura pubblica, lettura privata ovvero il petrarchismo al femminile'. Entro o fuori del modello?, [w:] Vita pubblica e vita privata nel Rinascimento. Atti del XX Convegno Internazinale (Chianciano Terme-Pienza 21-24.07.2008), red. Luisa Secchi Tarugi, Firenze 2010, s. 102-104.

${ }^{37}$ Zob. teksty Danièle Alexandre-Bindon La lettre volée. Apprendre à lire à l'enfant au Moyen Age, ,, Annales E.S.C.”, 4:1989, s. 953-992; Abécédaires et alphabets éducatifs du XIIe au XVe siecle, „Nouvelles de l'Estampe”, 90:1986, s. 6-10; Alphabets (14701700). A lire, à dire, à écrire, à broder, red. D. Alexandre-Bindon, Lyon 1990, s. 6-10. Także Le livre dans la vie quotidienne. Catalogue d'une exposition de la Bibliothèque Nationale de Paris, Paris 1975, s. 43-44 i 55. Por. Giovanni Battista Palatino, Libro [...] nel qual s'insegna a scrivere ogni sorte lettera, antica e moderna [...] con le sue regole \& misure, \& essempi [...], Roma 1545, k. [1r]. Na temat znaczenia mnemotechniki zob. J. Pietrzak-Thébault, Na progu nowoczesności. Renesansowa sztuka mnemotechniczna na przyktadzie „Dialogu o pamięci” Lodovica Dolce, „Forum Artis Rhetoricae”, 24(1):2011, s. 25-46. 


\section{Na służbie czyli między (pozornie) tradycyjną treścią a nowoczesnością przekazu}

Nie mamy ambicji, by uwagi na temat książek, które stały się tutaj osią naszego zainteresowania, ułożyły się w pełen i spójny obraz: wyzwań zmieniającej się rzeczywistości, czytelniczych oczekiwań i potrzeb, typograficznych osiagnięć. Zaprezentowane powyżej publikacje są zaledwie przykładami ukazującymi sposób, w jaki - w czasach, gdy druk był technologią młoda - rozkładało, a raczej - wiązało się, to, co dawne i to, co nowoczesne. Ufam, że bliższe przyjrzenie się tym, jakże często pogardzanym czy tylko niedostrzeganym przez badaczy, książeczkom, potrafi uzmysłowić nam to lepiej, niż studia nad niejedną książką „uczoną” i piękną. Ulica - jako nowe miejsce obecności książki, kobieta - jako jej nowa nie tylko użytkowniczka, lecz także adresatka, prace domowe i potrzebne na co dzień umiejętności, równocześnie odwołujące się do tradycyjnych przekazów i największych mistrzów, najpoważniejszych uczonych, najlepszych artystów - oto nieoczekiwany obraz książkowej służebnicy.

Co może jeszcze ciekawsze i ważniejsze, drukowane sługi codzienności sprzed ponad 500 lat nadal są przydatne i zdają się nie tracić wcale na aktualności. Bo jakkolwiek (pozornie) nie pełnia już swojej praktycznej funkcji, nieustająco zachwycają zarówno technologicznym nowatorstwem, odwagą w odkrywaniu nowych typograficznych dróg, jak i skromnym, ale niezaprzeczalnym pięknem.

\section{Streszczenie}

\section{Warząchiew, mydło, igła. Książka na służbie (Wenecja, XVI w.)}

Książka drukowana obecna była w Wenecji już od 1469 roku i bardzo szybko stałą się jedną ze specjalności miasta nad Laguną. Wśród wydań dzieł erudycyjnych, klasyków literatury łacińskej i toskańskiej oraz utworów autorów współczesnych, wraz z początkiem nowego stulecia ukazywać się zaczęły także wydania o tematyce praktycznej, przeznaczone do użytku codziennego. Książki te sprzedawane były często nie w księgarniach, a na ulicznych straganach i jarmarkach. Zbyt często pozostawały one na marginesie zainteresowań badaczy, jako nie wpisujące się łatwo w określony krąg czytelniczy. Ich tematyka dotyczyła zarówno przyrządzania potraw i sposobów przechowywania produktów, jak sporządzania w domu leków, mydeł i ,środków czystości” oraz wszelkiego 
rodzaju kosmetyków. Osobna, nader interesująca, kategorię stanowiły bardzo liczne wzorniki haftów i koronek igłowych - wzory nierzadko były dziełem największych artystów weneckich. Treści, jakie publikacje te upowszechniały były zwykle tradycyjne i służące najpospolitszym ludzkim, najczęściej kobiecym, zajęciom, lecz forma ich przekazu śmiało korzystała z najnowszych technologicznych i edytorskich osiagnięć weneckiego drukarstwa, co sprawia, że stanowią one do dzisiaj atrakcyjny i wdzięczny materiał do badań.

\section{Summary \\ Ladles, Soap, and Needles: The Popular Book in Sixteenth-Century Venice}

Printed books were present in Venice already in 1469 and quickly became one of the specialities of this city. But, with the beginning of the $16^{\text {th }}$ century, among the celebrated erudite works, classics of Latin, Tuscan, and contemporary literature, there appeared books treating practical matters, addressed to the common folk. Usually, these prints were sold not in bookshops, but from street stalls and in marketplaces. Unfortunately, these editions addressed to no particular milieu, hence, they seldom became the object of historical research. The themes treated by the authors of these publications range from cooking and food preservation to preparing homemade medicine, soap, cleaning agents, and various kinds of cosmetics. Needlework pattern books constitute a separate group among them. Not infrequent, and very interesting, these books contained works by the most distinguished artists active in Venice. Although, the content of such publications was very traditional and dealt with common activities, chiefly performed by women, their editorial form was state-of-the-art, and boldly utilised the most developed printing techniques of the time. In result, the books in question present very interesting material for research. 